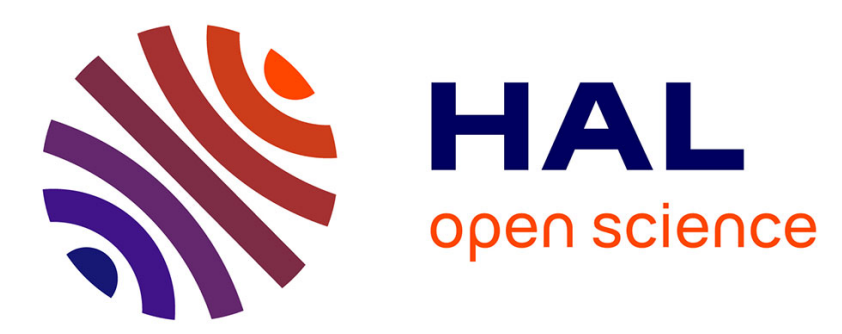

\title{
Evaluation of Customer-Oriented Power Supply Risk with Distributed PV-Storage Energy Systems
}

Mike Brian Ndawula, Antonio de Paola, Ignacio Hernando-Gil

\section{To cite this version:}

Mike Brian Ndawula, Antonio de Paola, Ignacio Hernando-Gil. Evaluation of Customer-Oriented Power Supply Risk with Distributed PV-Storage Energy Systems. Risk Day 2019 - EPSRC Supergen Energy Networks Hub, Mar 2019, Cambridge, United Kingdom. hal-02446319

\section{HAL Id: hal-02446319 https://hal.science/hal-02446319}

Submitted on 20 Jan 2020

HAL is a multi-disciplinary open access archive for the deposit and dissemination of scientific research documents, whether they are published or not. The documents may come from teaching and research institutions in France or abroad, or from public or private research centers.
L'archive ouverte pluridisciplinaire HAL, est destinée au dépôt et à la diffusion de documents scientifiques de niveau recherche, publiés ou non, émanant des établissements d'enseignement et de recherche français ou étrangers, des laboratoires publics ou privés. 


\title{
Evaluation of Customer-Oriented Power Supply Risk with Distributed PV-Storage Energy Systems
}

\author{
Mike Brian Ndawula1, Antonio De Paola1, Ignacio Hernando Gil²
}

\begin{abstract}
Accurate reliability evaluation raises customer WTP.

$>$ System-oriented evaluation masks poor reliability performance.

$>$ Different customer perceptions of DNO services' value.
\end{abstract}

\section{Customer Priorities in a Climate of Rising Energy Prices}

Perception of the DNO's $18 \%$ share of the electricity bill

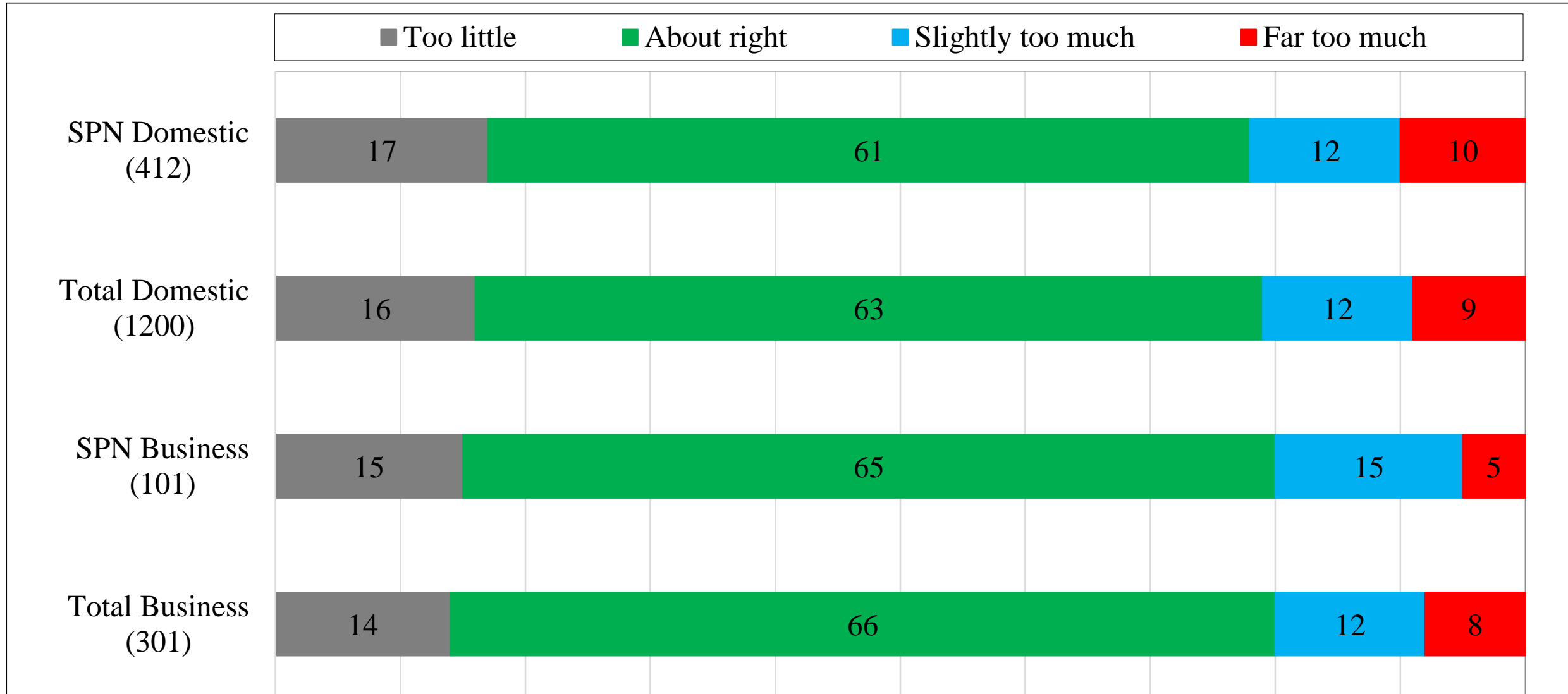

DNO services valued most highly are;

$>$ Rapid supply restoration.

$>$ Quicker detection of supply loss.

$>$ Carbon reduction initiatives.
Customer WTP for increases in DNO service levels

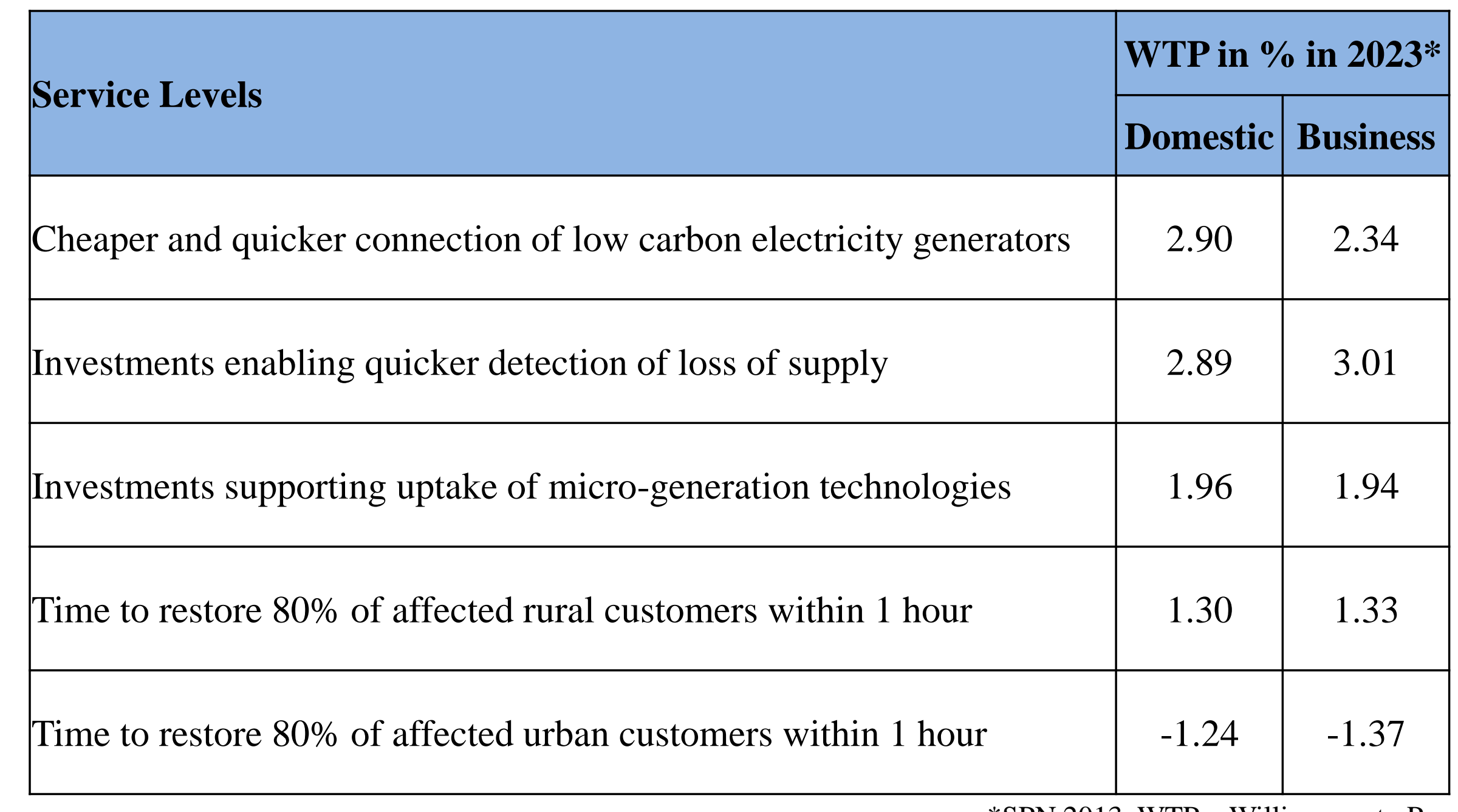

\section{Integrated Quality of Supply Analysis}

Urban MV Network

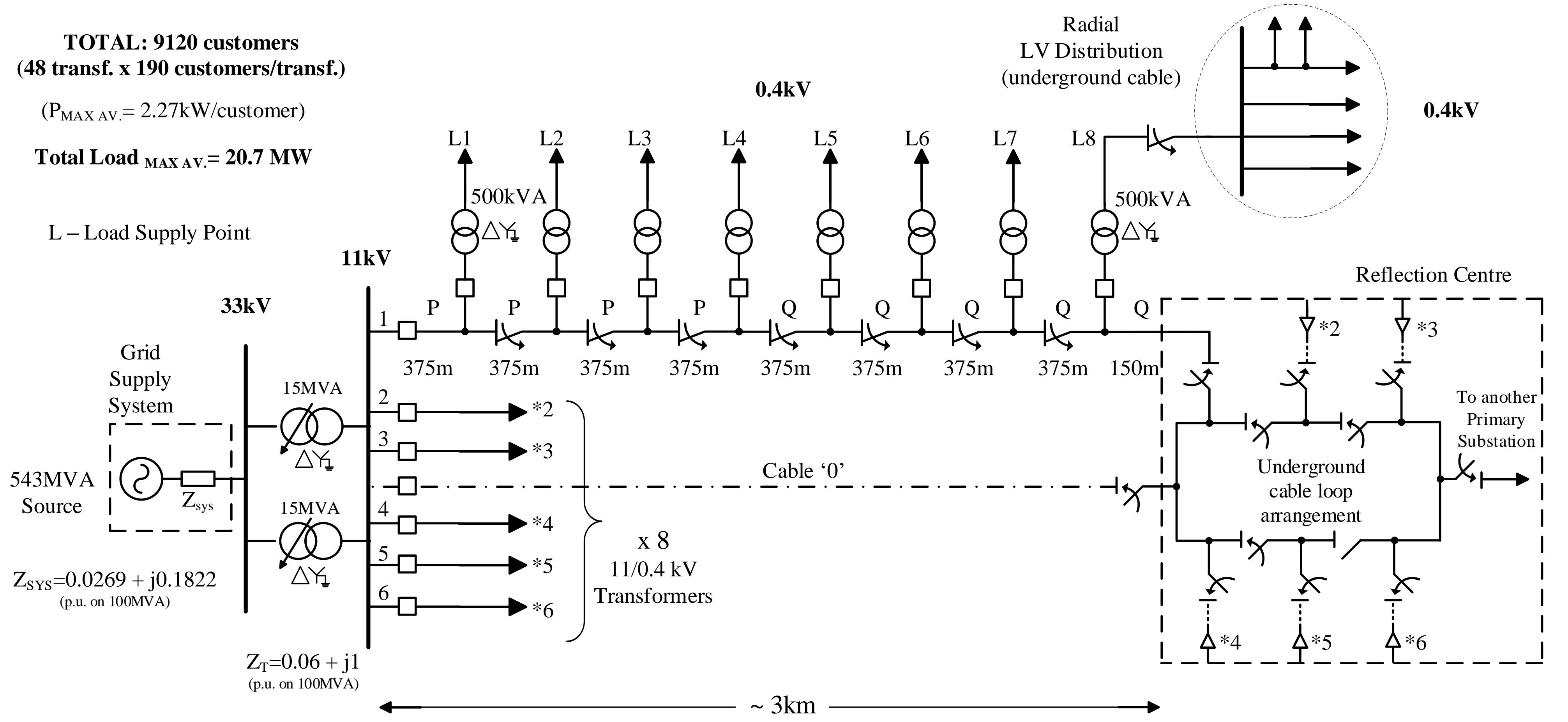

After Diversity Maximum

Demand: $2.27 \mathrm{~kW} /$ customer
$>$ LV aggregate networks with reliability equivalents
Monte-Carlo simulation enhanced by including:

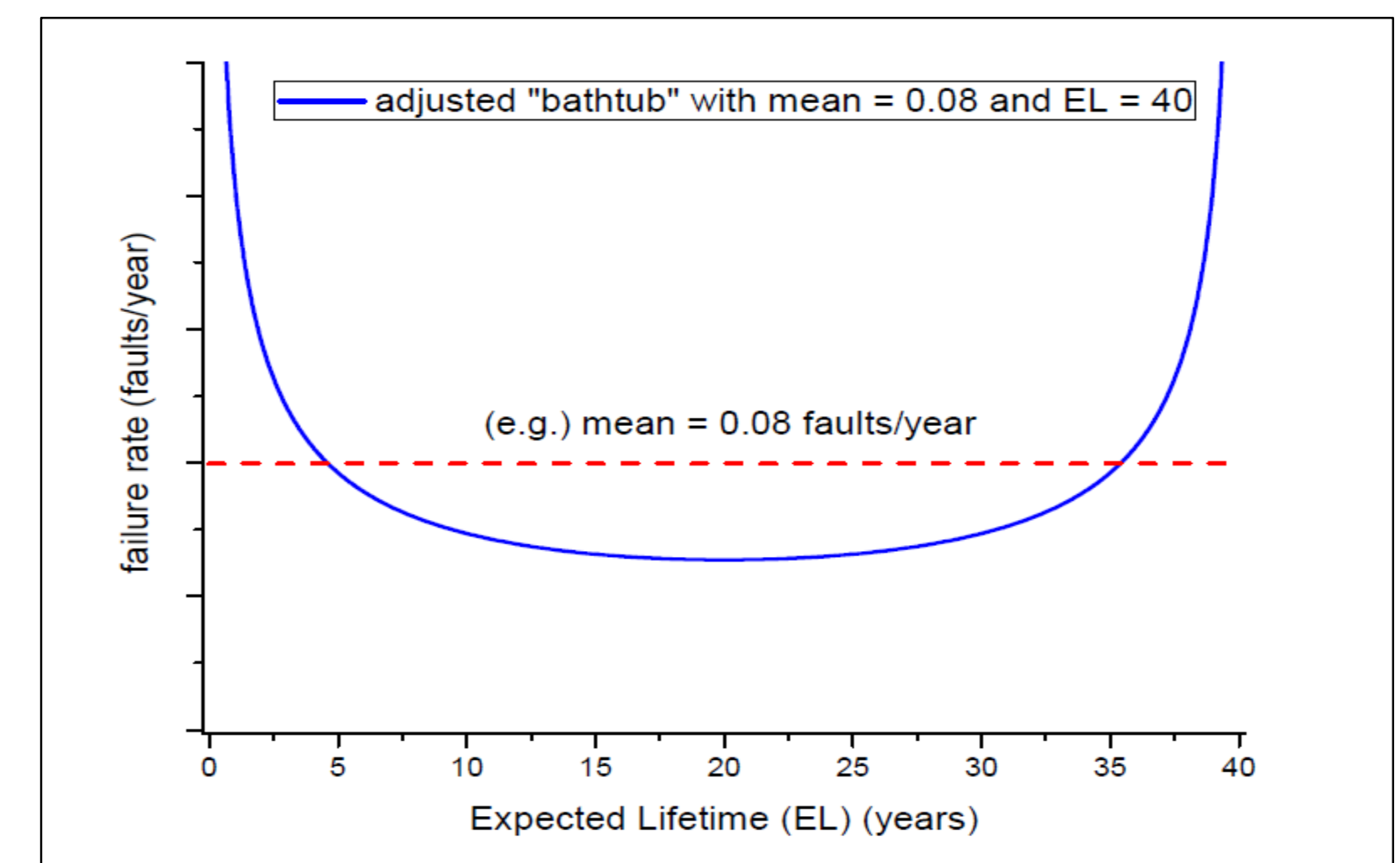

$>$ Time-varying component failure rates.

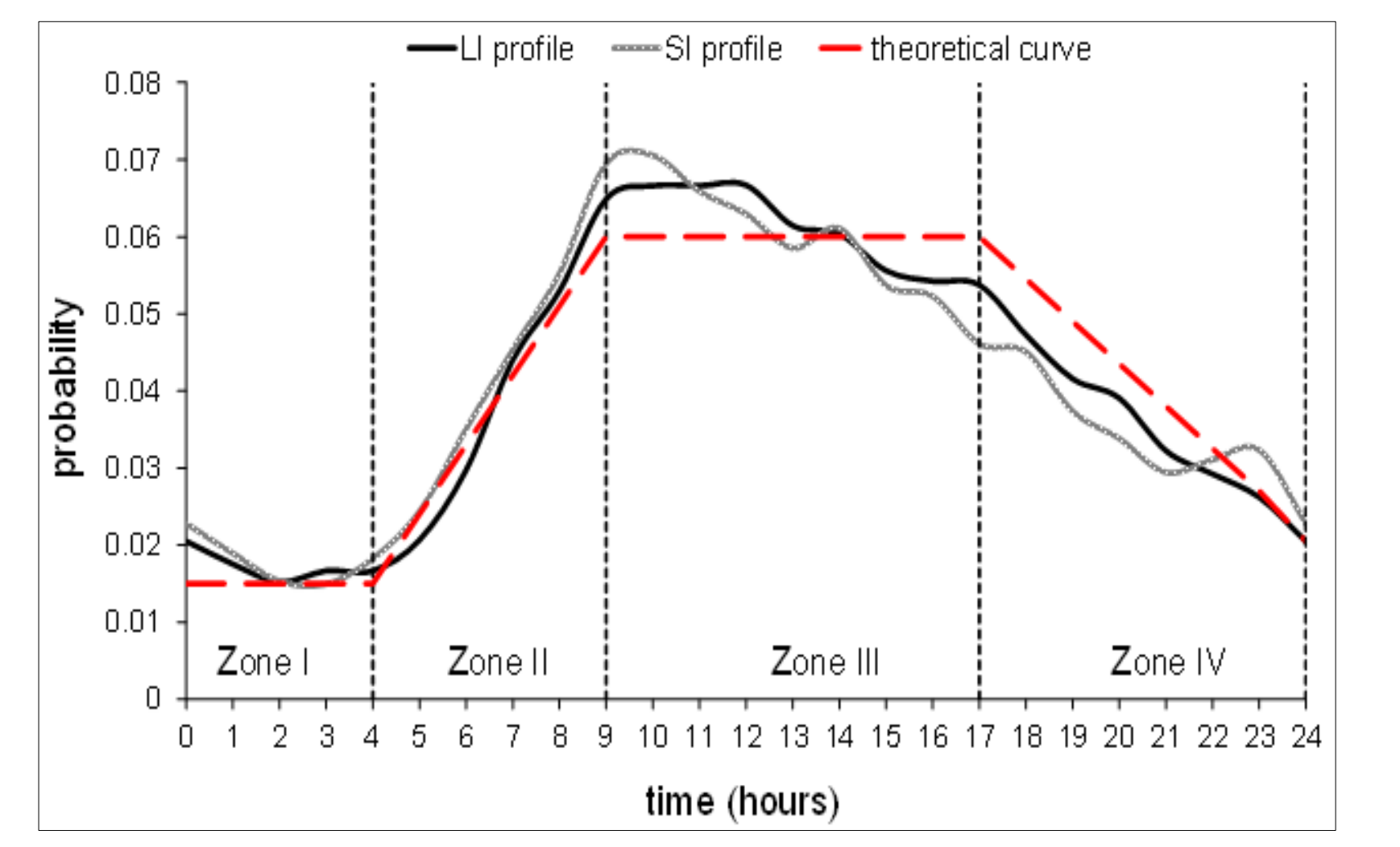

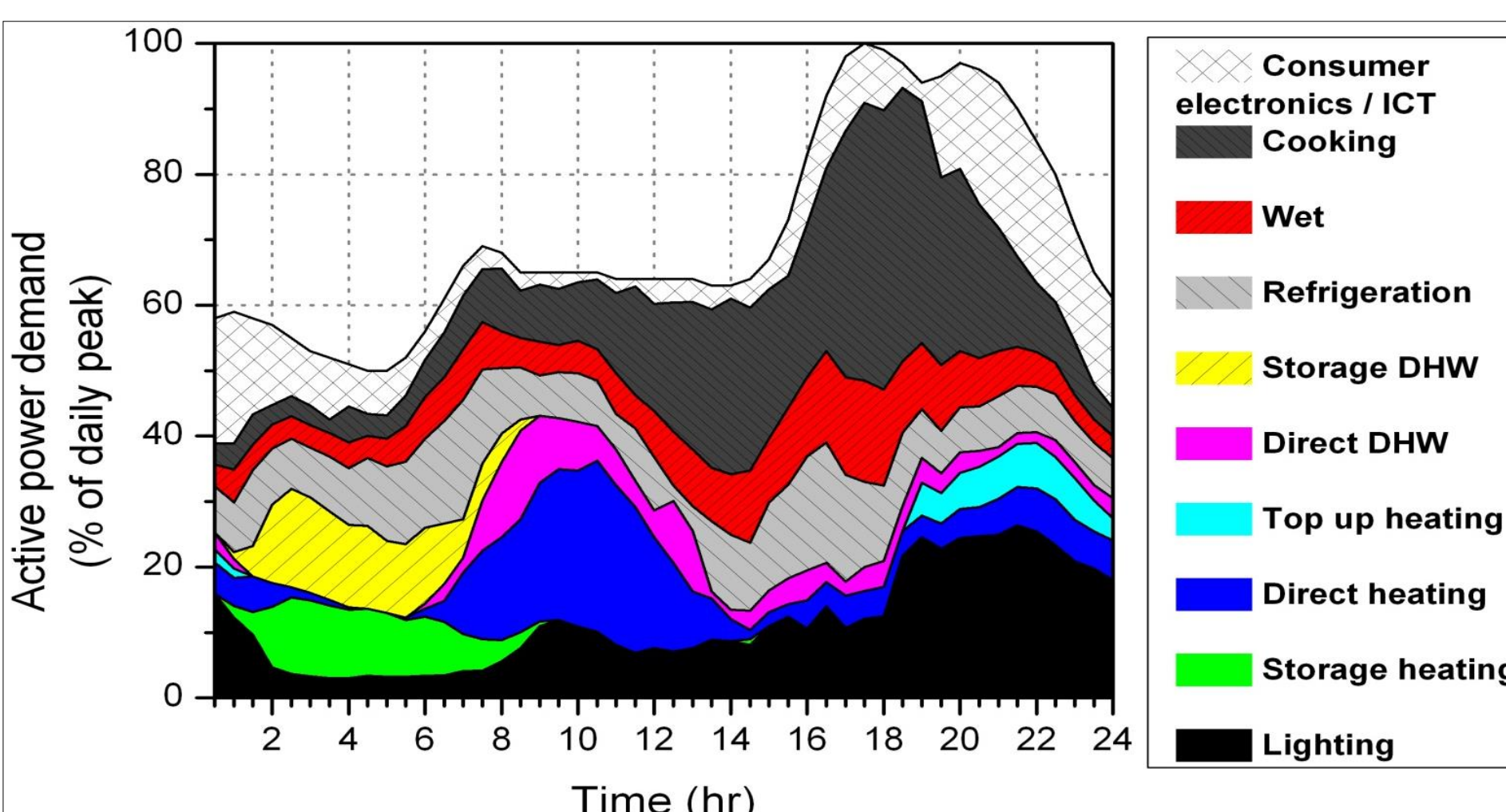

$>$ Time-varying demand profiles.

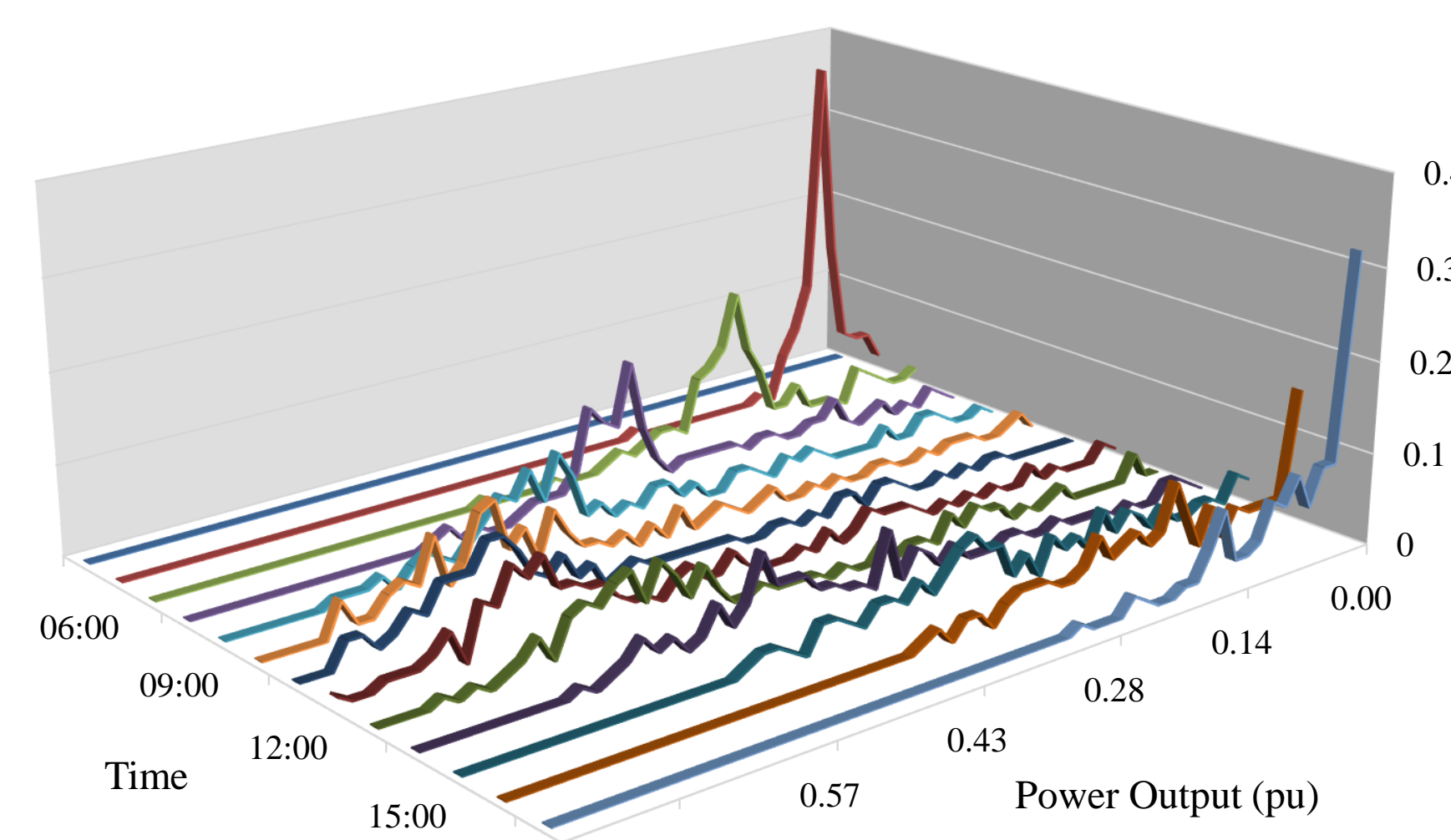

$>$ Daily probabilities of long/short interruptions. $>$ Spatial-temporal variation of PV

\section{Customer-Oriented Reliability Evaluation}

\section{Reliability Enhancement}

1) PV+DSR - Uncontrolled solar photovoltaic (PV) energy with a $50 \%$ overall network penetration, and demand-side response (DSR) designed for reliability improvement through load reductions during periods with high fault-probability.

2) ES + DSR - Energy Storage (ES) where daily Microgeneration output is controlled by an energy management system to provide a backup capability of $3.67 \mathrm{kWh}$ per customer per fault, coupled with DSR.

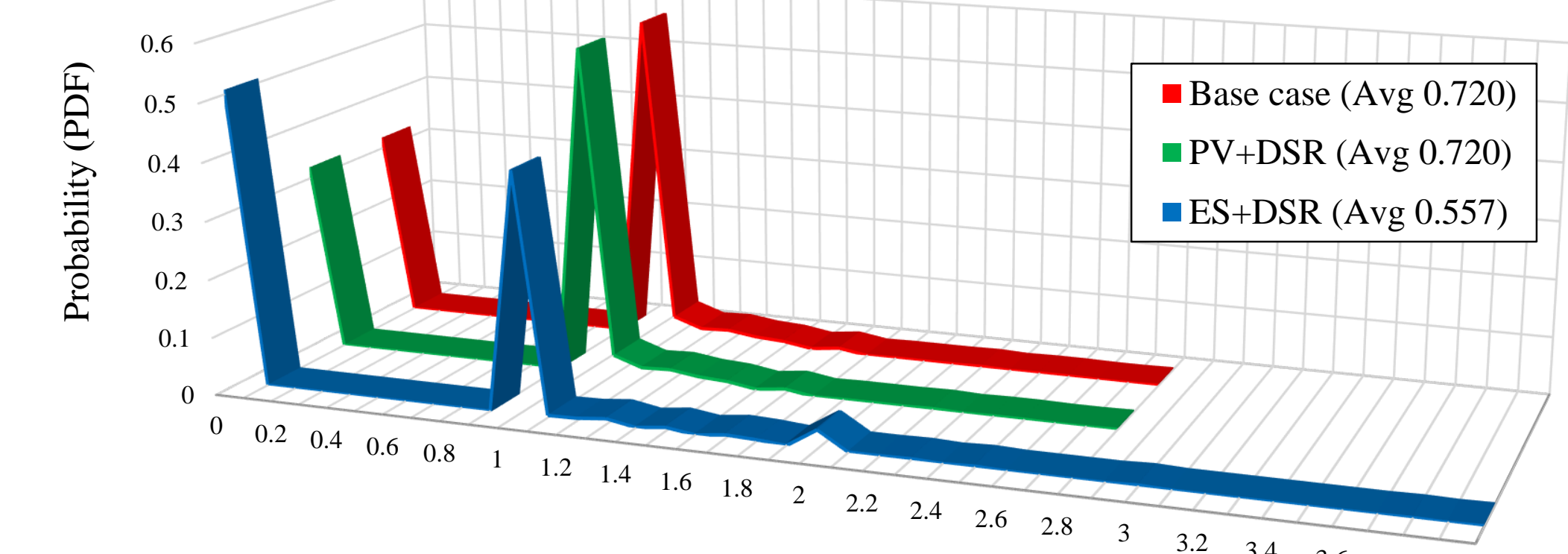

Impact of the frequency of long interruptions

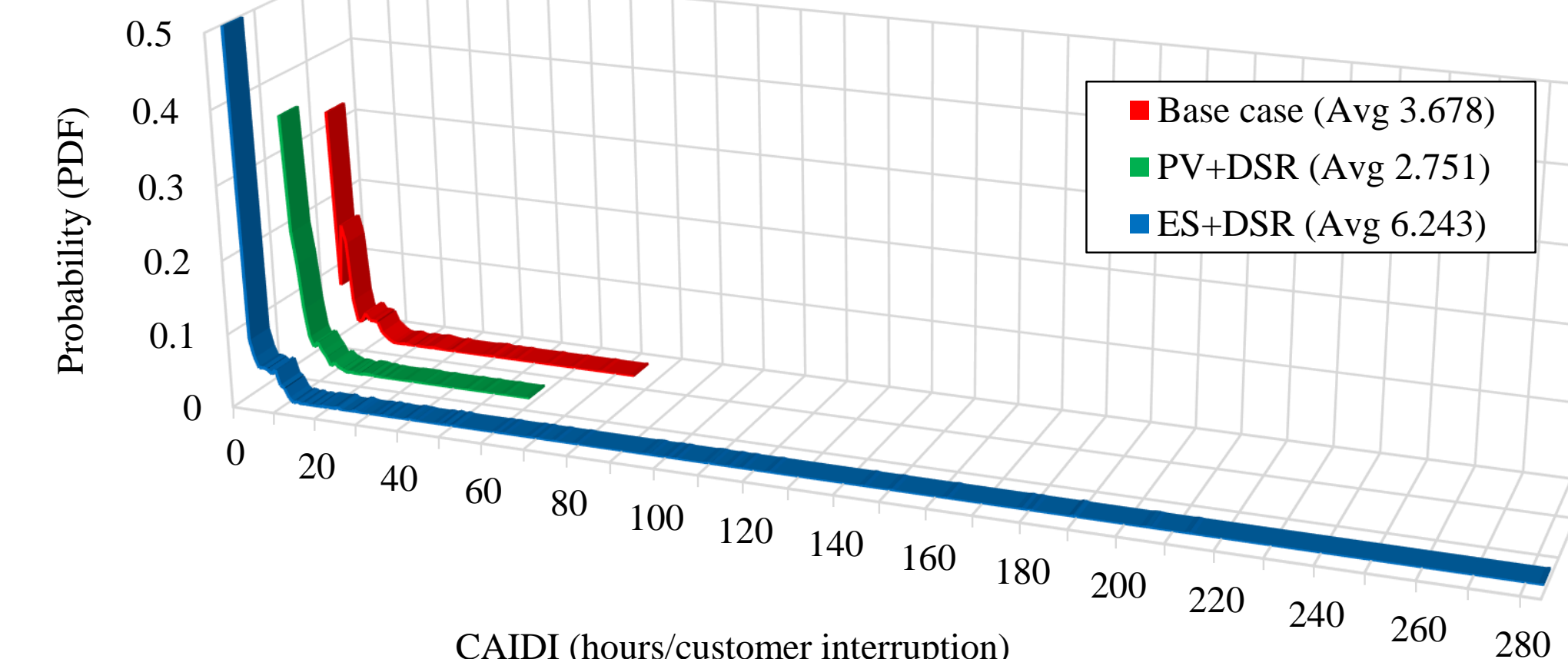

Impact of the duration of long interruptions.

\section{Comprehensive Reliability Assessment}

$>$ Each customer index is significantly larger than its system equivalent.

$>$ ES+DSR significantly alleviates impacts of long interruptions but

$>$ Has negligible impact on short interruptions.
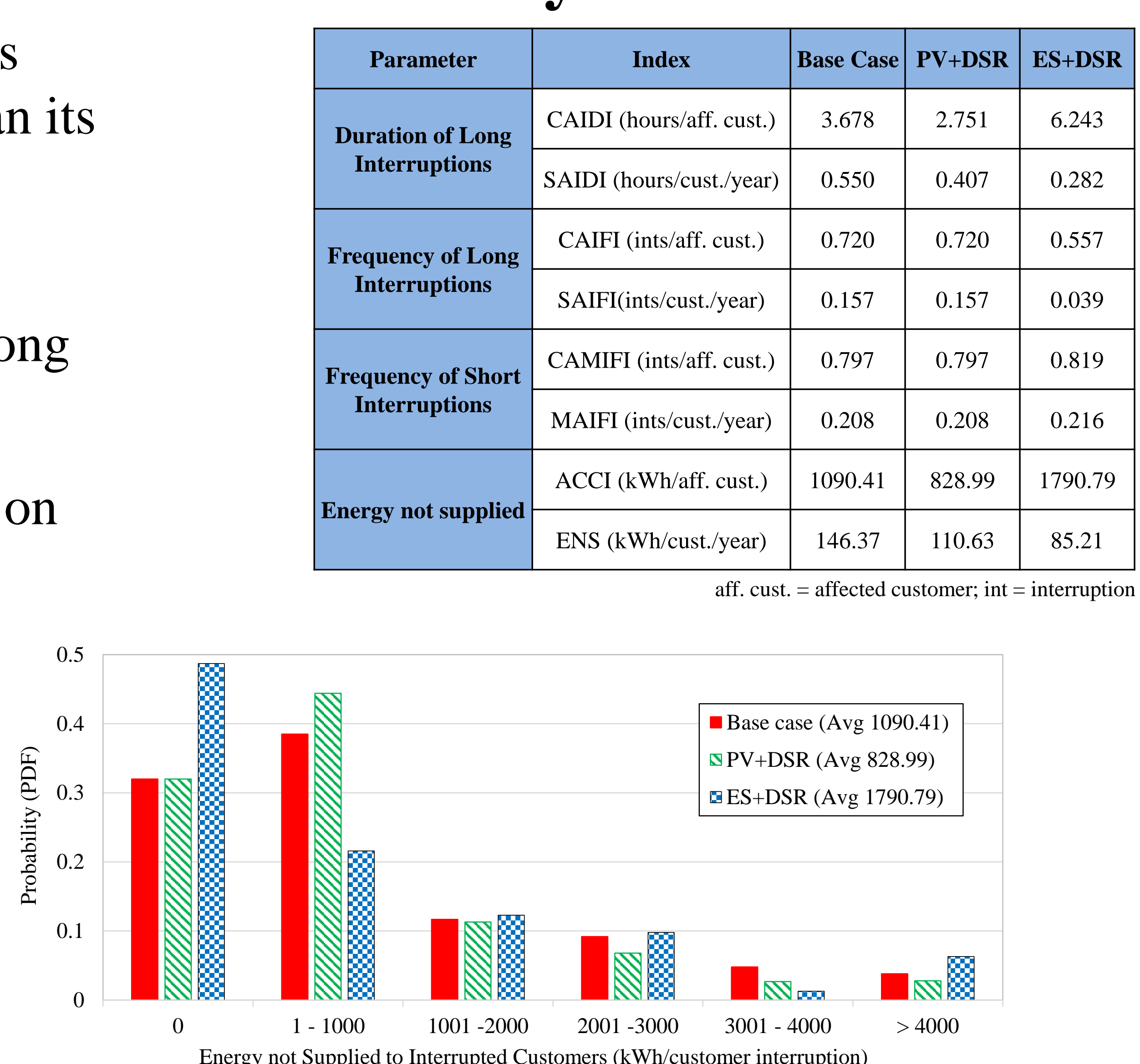

Probability of ENS to interrupted customers.

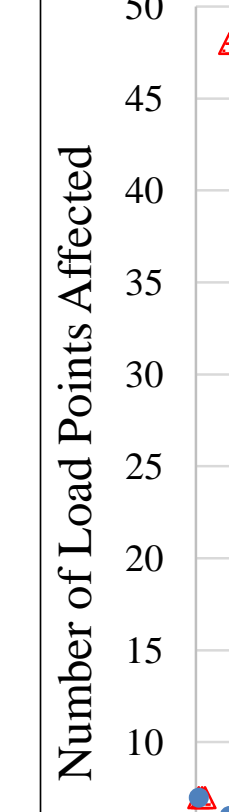

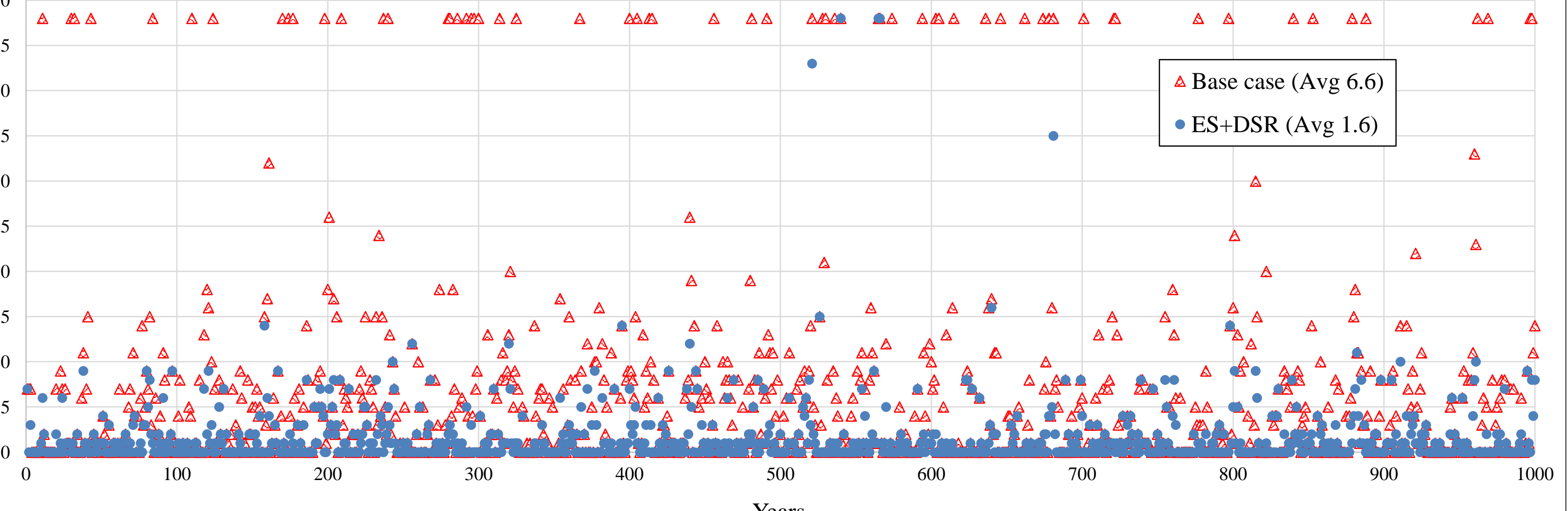

Number of network load points affected by supply interruptions.
- PV-storage systems offer reductions in the average frequency and duration of interruptions, number of affected load points, and the subsequent ENS.

- Customer WTP is enhanced by customer-oriented reliability evaluation through:

$>$ More accurate quantification of perceived customer reliability.

$>$ Confidence in DNO-reporting on power delivery.

$>$ Supporting the uptake of distributed energy resources e.g. PV.

- Reliability-based customer identification enables DNOs to effect impactful network improvements, and consistently exceed regulator-set performance targets. 